\title{
In vitro analysed effects of two different in vivo administered lidocaine dosages on the equine jejunal smooth muscle challenged by an ischemia-reperfusion-injury-model (IRIM)
}

\author{
Frauke Uhlendorf', Maria Guschlbaver², Susanne Hoppe ${ }^{2}$, Korinna Huber ${ }^{2}$ and Karsten Feige ${ }^{1}$ \\ Clinic for Horses ${ }^{1}$ and Department of Physiology ${ }^{2}$, University of Veterinary Medicine, Hannover, Germany
}

\begin{abstract}
Summary
Lidocaine as a prokinetic drug is acting dose-dependently on the ischemia-reperfusion (IR) injured equine jejunal smooth muscle. The aim of the study was to examine the effects of different dosages of lidocaine on jejunal smooth muscle contractility in vitro as a basic research approach to examine the potential mechanism of lidocaine. Sustainability of this in vivo effect of applied lidocaine was tested under in vitro conditions. Hypothesis: Application of a higher initial dose of lidocaine during IR in vivo could change, improve or even impair the contractility effects on jejunal smooth muscle in vitro. 12 horses received either a $1.3 \mathrm{mg} / \mathrm{kg}$ (IRL $; ; \mathrm{N}=7)$ or $2.6 \mathrm{mg} / \mathrm{kg}$ (IRL2; $\mathrm{N}=5$ ) lidocaine bolus infusion over 10 minutes followed by $0.05 \mathrm{mg} / \mathrm{kg} / \mathrm{min}$ intravenously for 5 minutes while artificial IR injury on the jejunum was induced. To examine the effects of lidocaine on jejunal smooth muscle function, isometric force performance (amplitude, frequency and contractility) was measured in vitro at two different times $(t 1,+2)$. The influence of either in vitro lidocaine supplementation $(K H B+L)$ or no supplementation $(\mathrm{KHB})$ was studied to assess the sustainability of lidocaine effects. IRL2 $\mathrm{KHB}+\mathrm{L}$ showed a significant higher frequency of contraction at +2 compared to IRL $1 \mathrm{KHB}+\mathrm{L}$. Amplitude of contractions and contractility were significantly decreased in the IRL $1 \mathrm{KHB}$ tissues compared to IRL1 KHB $+\mathrm{L}$ at +2 . The IRL2 KHB tissues at +2 showed a significant decrease of frequency and amplitude of contractions compared to the IRL2 KHB $+\mathrm{L}$. There was a significant decrease in frequency and an increase in amplitude of contractions and in contractility in IRL $1 \mathrm{KHB}+\mathrm{L}$ from +1 to +2 . In IRL1 KHB a significant decrease in frequency was observed but increase in amplitude of contractions and contractility was lacking from +1 to +2 . IRL2 KHB expressed a significant decrease in frequency and a significant increase in amplitude from $\dagger 1$ to +2 , while amplitude, frequency and contractility in IRL2 KHB $+\mathrm{L}$ were not influenced by time. High dosage lidocaine bolus infusion with further supplementation increased frequency of contractions and maintained amplitude of contractions over the experimental time. This in vitro study suggested that immediate application of a high bolus dosage may improve protective effects of lidocaine furthermore in vitro. At the moment, no pharmacokinetic data for a $2.6 \mathrm{mg} / \mathrm{kg}$ over $10 \mathrm{~min}$. lidocaine bolus in vivo is available. Recommending a higher initial lidocaine bolus in vivo, especially because of negative side effects, requires further investigation.
\end{abstract}

Keywords: lidocaine / equine jejunum / contractility / smooth muscle / prokinetic effects / anesthesiology / horse

In vitro untersuchte Effekte von zwei unterschiedlichen in vivo verabreichten Lidokaindosierungen auf die glatte Muskulatur des equinen Jejunums in einem Ischämie-Reperfusions-Modell

Lidokain wirkt dosisabhängig prokinetisch auf die Ischämie-Reperfusion (IR) geschädigte glatte Muskulatur des equinen Jejunums. Ziel dieser Studie war, die Effekte unterschiedlicher Lidokaindosierungen in vivo auf die Kontraktilität der glatten Muskulatur des equinen Jejunums in vitro zu untersuchen. Dieser experimentelle Grundlagenansatz soll zum Verständnis möglicher Wirkungsmechanismen von Lidokain beitragen. Zusätzlich wurde die Nachhaltigkeit der in vivo ausgelösten Effekte unter in vitro Bedingungen überprüft. Hypothese: Die Applikation eines hohen initialen Lidokainbolus in vivo während der IR könnte die Kontraktilität der glatten Muskulatur des Jejunums in vitro verändern, verbessern oder sogar negativ beeinflussen. Während eines artifiziell induzierten Ischämie-Reperfusionsschadens des Jejunums erhielten 12 Pferde entweder eine $1,3 \mathrm{mg} / \mathrm{kg}$ (IRL1; $\mathrm{N}=7$ ) oder 2,6 mg/kg (IRL2; $\mathrm{N}=5$ ) Lidokainbolusinfusion über 10 Minuten gefolgt von einer Erhaltungsdosis von $0,05 \mathrm{mg} / \mathrm{kg} / \mathrm{min}$ i.v. über 5 Minuten. Um den Effekt von Lidokain auf die glatte Muskulatur des Jejunums zu untersuchen wurde die isometrische Kontraktionskraft (Amplitude, Frequenz und Kontraktilität) in vitro an zwei verschiedenen Zeitpunkten $(\dagger 1,+2)$ beurteilt. Der Einfluss einer weiteren Lidokainsupplementation in vitro $(\mathrm{KHB}+\mathrm{L}$ ) oder keiner weiteren Supplementation (KHB) wurde evaluiert, um die Nachhaltigkeit des Lidokaineffekts zu überprüfen. Die Kontraktionsfrequenz der IRL2 KHB $+\mathrm{L}$ war im Vergleich zur IRL 1 KHB + L signifikant höher zum Zeitpunkt †2. Die Amplitude der Kontraktion und die Kontraktilität der glatten Muskulatur des Jejunums waren bei der IRL1 KHB zum Zeitpunkt +2 im Vergleich zur IRL1 KHB + L signifikant reduziert. Die IRL2 KHB zeigte zum Zeitpunkt †2 im Vergleich zur IRL2 KHB $+\mathrm{L}$ eine signifikant verminderte Frequenz und Amplitude der Kontraktion. Innerhalb der IRL1 KHB $+\mathrm{L}$ konnte eine signifikante Abnahme der Frequenz sowie ein Anstieg der Amplitude und der Kontraktilität zwischen †1 und †2 festgestellt werden. Die IRL1 $\mathrm{KHB}$ zeigte ebenfalls im Vergleich von tl zu t2 einen Abfall der Kontraktionsfrequenz, ein Anstieg der Kontraktionsamplitude und der Kontraktilität konnte nicht festgestellt werden. Die IRL2 KHB zeigte einen signifikanten Frequenzabfall und einen Amplitudenanstieg im Vergleich zwischen †1 und †2 während bei der IRL2 KHB +L keine Veränderungen von Amplitude, Frequenz und Kontraktilität über die Zeit festgestellt werden konnten. Die höher dosierte Lidokainbolusinfusion mit zusätzlicher Zugabe von Lidokain in vitro erzielte eine stetigere Kontraktilität der glatten Muskulatur im Vergleich zur niedriger dosierten Bolusinfusion. Diese In vitro-Studie deutet darauf hin, dass die Applikation eines hoch dosierten Bolus die protektiven Effekte von Lidokain noch weiter verbessern kann. Da zu diesem Zeitpunkt keine pharmakokinetischen Daten für einen Lidokainbolus von $2,6 \mathrm{mg} / \mathrm{kg}$ über 10 Minuten verfügbar sind, bedarf der Vorschlag eines höheren Lidokainbolus in vivo vor allem wegen der möglichen unerwünschten Arzneimittelwirkungen weiterer Untersuchung.

Schlüsselwörter: Lidokain / equines Jejunum / Kontraktilität / glatte Muskulatur / prokinetische Effekte / Anästhesie / Pferd 


\section{Introduction}

Lidocaine, an amide-type local anaesthetic, is used for various purposes in veterinary medicine. Besides its local anesthetic effects, lidocaine is used for antiarrhythmic and antiepileptic treatment (Löscher et al. 2003). Furthermore, lidocaine is known to have protective and/or prokinetic effects on intestinal smooth muscle (Nieto et al. 2000, Guschlbaver et al. 2010a) and heart muscle (Takeo et al. 1989) after ischemia-reperfusion (IR) injury although the mechanism of its protective and prokinetic effects are still unclear. Administration of lidocaine significantly decrease liberation of substances from body cells such as hypoxiainduced release of creatine kinase from the intestinal smooth muscle (Guschlbaver et al. 2010a) and from the heart muscle (Takeo et al. 1989), and attenuates inflammatory response by decreasing the plasma concentrations of complement factors and pro-inflammatory cytokines released by inflammatory cells (Herroeder et al. 2007).

Previous studies revealed that in vitro lidocaine supplementation of $25 \times 10^{9} \mathrm{ng} / \mathrm{ml}=25 \mathrm{mg} / \mathrm{L}=10^{-4} \mathrm{~mol} / \mathrm{L}$ is needed to improve effectively contractile activity of the equine jejunal smooth muscle (Guschlbaver et al. 2010a, Nieto et al. 2000). After continuous infusion of lidocaine as used in the treatment of post operative ileus (POI) (bolus of $1.3 \mathrm{mg} / \mathrm{kg}$ over $10 \mathrm{~min}$. followed by continuous rate infusion (CRI) of $0.05 \mathrm{mg} / \mathrm{kg}$ ) plasma lidocaine concentrations increased up to approximately $1000 \mathrm{ng} / \mathrm{ml}$ after 3 hours and remained stable at approximately $950 \mathrm{ng} / \mathrm{ml}$ over a 96 hour infusion period (van Hoogmoed et al. 2004, Navas de Solis and McKenzie III 2007, Dickey et al. 2008). Only approximately one-tenth of these plasma concentrations (Mean \pm standard error of the mean (SEM) $97.2 \pm 17.7 \mathrm{ng} / \mathrm{ml}, \mathrm{n}=12$ ) were achieved after an in vivo lidocaine bolus of $1.3 \mathrm{mg} / \mathrm{kg}$ over $10 \mathrm{~min}$. followed by 0.05 $\mathrm{mg} / \mathrm{kg}$ over $5 \mathrm{~min}$. during the ischemic period of an IRIM. Lidocaine tissue concentrations in jejunal smooth muscle achieved $133.9 \pm 24.5 \mathrm{ng} / \mathrm{mg}$ tissue wet weight measured directly after resection (Guschlbaver et al. 2011). Lack of lidocaine pharmacokinetics in healthy and IRIM horses causes difficulties in extrapolation of in vitro effective lidocaine concentrations of organ bath buffers into in vivo effective CRI concentrations.

Recent in vitro studies were performed with isolated circular smooth muscle of distal equine jejunum to determine the influence of lidocaine on smooth muscle contractility. Experiments were performed in healthy and artificially $I R$ challenged jejunal smooth muscle, demonstrating that intestinal smooth muscle contractility responded dose-dependently to lidocaine supplementation in vitro and that IR-injured smooth muscle is more susceptible to lidocaine (Guschlbaver et al. 2010a, $2011)$. Lidocaine was able to restore contractility of IR-injured smooth muscle to the level of healthy smooth muscle, indicating a repair mechanism (Guschlbaver et al. 2010a). The in vivo application of lidocaine $(1.3 \mathrm{mg} / \mathrm{kg}$ IV bolus followed by 0.05 $\mathrm{mg} / \mathrm{kg} / \mathrm{min}$ IV as a continuous infusion) during artificial IR increased contractility and frequency of contractions in vitro compared to untreated IR-injured smooth jejunal muscle. Hence lidocaine is also able to prevent smooth muscle injury provoked by artificial IR. When additional in vitro lidocaine supplementation was performed after in vivo application, contractility could further be improved (Guschlbaver et al. 2011). However, very high dosages of lidocaine in vitro reduce contractile performance of smooth muscle (decreasing in vitro contractility after supplementing 100-400 $\mathrm{mg} / \mathrm{l})$ indicating an accumulation within the muscle cell (Guschlbauer et al. 2010a).

Based on the latter results of the recent in vitro studies, it was hypothesised that the short-term application of a higher initial dose of lidocaine during IR in vivo could change, improve or even impair the contractility effects on jejunal smooth muscle in vitro. To test the effects of a higher dosage on smooth muscle contractility in vitro, artificially IR-injured tissues of horses infused with two different lidocaine dosages in vivo were analyzed for basic contractility and for their responsiveness to additionally supplemented lidocaine in vitro. Furthermore, sustainability of these effects was tested.

\section{Material and Methods}

Animals

Twelve adult horses randomly divided into two groups were used in this study. The first group (IRL 1: ischemic and reperfused, with in vivo lidocaine infusion dose $1=1.3 \mathrm{mg} / \mathrm{kg} / 10$ min. IV followed by $0.05 \mathrm{mg} / \mathrm{kg} / 5 \mathrm{~min}$. IV) consists of six mares and one gelding $(N=7)$. Six of these horses with a mean age of 13.4 years were warmblood horses and one was a Thoroughbred. The second group (IRL2: ischemic and reperfused, with in vivo lidocaine infusion dose $2=2.6 \mathrm{mg} / \mathrm{kg} / 10 \mathrm{~min}$. IV followed by $0.05 \mathrm{mg} / \mathrm{kg} / 5 \mathrm{~min}$. IV) with a mean age of 15.6 years included one gelding, one stallion and three mares $(\mathrm{N}=$ 5). Three horses were warmblood horses, one horse was a Standardbred and one a Thoroughbred. All horses were healthy and showed no gastrointestinal disorders. Horses were kept on hay and water ad libitum two weeks prior to surgery.

\section{Surgical procedure of ischemia-reperfusion injury}

Following general anesthesia and ventral laparotomy in dorsal recumbency all horses underwent an IRIM as described previously (Guschlbaver et al. 2010a, 2011). All animal procedures were approved by the State Office for Consumer Protection and Food Safety in accordance with the German Animal Welfare Law.

\section{In vivo lidocaine infusion protocol}

Directly after ligation of the mesenteric vessels and luminal closure (ischemia), infusion of lidocaine using a $2 \%$ commercially available solution (Lidocaine, bela pharm, Vechta, Germany) was commenced. Horses in the IRL I-group received a loading bolus infusion lasting 10 minutes $(1.3 \mathrm{mg} / \mathrm{kg} \mathrm{IV})$ followed by a CRI of $0.05 \mathrm{mg} / \mathrm{kg} / \mathrm{min}$ IV for 5 minutes. The IRL2group received a higher loading bolus infusion lasting 10 minutes $(2.6 \mathrm{mg} / \mathrm{kg} \mathrm{IV})$ followed by a CRI of $0.05 \mathrm{mg} / \mathrm{kg} / \mathrm{min}$ IV for the remaining 5 minutes of the ischemic period.

\section{Tissue preparation}

Immediately after resection the segment was divided into 2 parts. One part (KHB: Krebs-Henseleit-Buffer without lidocai- 
ne supplementation, 4 muscle strips/horse, $\mathrm{nIRL} 1=28$, nIRL2 $=20$ ) was transferred into a modified Krebs-HenseleitBuffer (in mmol/L: $117.0 \mathrm{NaCl}, 4.7 \mathrm{KCl}, 2.5 \mathrm{CaCl}_{2}, 1.2$ $\mathrm{MgCl}_{2}, 1.2 \mathrm{NaH}_{2} \mathrm{PO}_{4}, 25.0 \mathrm{NaHCO}^{3}, 11.0$ glucose, gassed with $95 \% \mathrm{O}_{2}$ and $\left.5 \% \mathrm{CO}_{2}\left(\mathrm{pH} 7.4,38^{\circ} \mathrm{C}\right)\right)$. The other part of the resected jejunal segment was transferred into Krebs-Henseleit-Buffer which was supplemented with $25 \mathrm{mg} / \mathrm{L}$ lidocaine $(\mathrm{KHB}+\mathrm{L}$ : Krebs-Henseleit-Buffer with lidocaine supplementation $25 \mathrm{mg} / \mathrm{L}$, 8 muscle strips/horse, $\mathrm{nIRL} 1=56$, nIRL2 = 40). This dosage was set to be optimal effective by preliminary in vitro studies which showed a dose-dependent response of in vitro measured contractility to lidocaine reaching "steady-state" at lidocaine concentrations ranging between 20 and $100 \mathrm{mg} / \mathrm{L}$ (Guschlbaver et al. 2010a). Tissue was prepared as previously described by (Guschlbaver et al. 2010a, $2011)$. Briefly, strips of the circular smooth muscle of equal size and weight were prepared from each horse of IRL 1 and IRL2 and mounted into the force measurement apparatus fitted with isometric force transducers. Eight $\mathrm{KHB}+\mathrm{L}$ strips $(\mathrm{n}=8)$ were prepared per horse and mounted into an organ bath filled with $10 \mathrm{ml} \mathrm{KHB}+25 \mathrm{mg} / \mathrm{L}$ lidocaine. Furthermore, four KHB strips $(n=4)$ were prepared per horse and were mounted in organ baths without supplementation of lidocaine. The initial tension of all muscle strips was adjusted to $2 \mathrm{~g}$, because preliminary studies showed that $2 \mathrm{~g}$ of tension resulted in optimal muscle length for maximal isometric force development in the jejunum (Nieto et al. 2000). To study the effects of lidocaine on smooth muscle cells and interstitial cells of Cajal (ICC) only, the tissue strips in the organ bath were treated with tetrodotoxin (TTX $1 \mathrm{~mol} / \mathrm{L}$ ) in order to deactivate the enteric nervous system neurons. A successful inhibition was validated by lack of response to electric field stimulation (Boddy et al. 2004).

\section{Measurement of basal contractile activity}

After equilibration (acclimatization to the in vitro conditions of the smooth muscle strips over 30 minutes) the basal contractility (= contractility after deactivation of the enteric nervous system with TTX) was recorded for 205 minutes. With TTX treated equine jejunal muscle strips show spontaneous contractions (basal contractility) mediated by the electric pacemaker function of ICCs (Takaki 2003, Fintl et al. 2004) without any neuronal participation. These spontaneous contractions can be defined by amplitude (isometric force of contraction, $\mathrm{mN}$ ) and by frequency (peaks/min). By use of these 2 variables, the area under the curve (AUC) for all contractions within one minute (contractility, $\mathrm{mN} / \mathrm{min}$ ) was calculated. Amplitude, frequency of contractions and contractility were analyzed at minute 10-25 ( +1$)$ and minute 65-80 (†2) after equilibration. Contractions of smooth muscle samples were digitalized with a chart recorder $(4.8 \mathrm{kHz} / \mathrm{DC})$ and data were collected digitally (Spider 8 chart recorder and Catman Easy software, version 1.01, HBM).

\section{Statistical analysis}

Data were given as means \pm SEM of $N=7$ in IRL 1 and $N=5$ in IRL2. Significance of difference of basal contractility, frequency of contractions and amplitude was statistically tested between IRL1 and IRL2 with unpaired Student's t test.
When comparing contractility, frequency and amplitude within one group (IRL1 or IRL2) but at different times ( $t 1$ or +2 ) or different buffer containing ( $\mathrm{KHB}$ or $\mathrm{KHB}+\mathrm{L}$ ) paired Student's t-test was used for statistical analysis (graphpad.prism, version 4.0, GraphPad Software Inc). The level of statistic significance $(p)$ was set at $p<0.05\left(^{*}\right), p<0.01\left(^{* *}\right), p<0.001$ $(* * *)$.

\section{Results}

Effects of different lidocaine dosages applied in vivo on contractility of jejunal smooth muscle in vitro

To assess the only effect of the higher lidocaine bolus dosage contractile performance of IRL1 and IRL2 intestinal smooth muscle at either +1 or $\nmid 2$ were compared. This was done for $\mathrm{KHB}+\mathrm{L}$ muscle strips and for KHB strips separately. The mean frequency of contractions, amplitude and contractility did not differ between IRL1 and IRL2 tissue at +1 and +2 with one exception, the significant higher frequency $(p<0,01)$ in the $\mathrm{KHB}+\mathrm{L}$ tissue of IRL2 group at $+2(7,0 \pm 0,75$ peaks/min, $\mathrm{n}$ IRL2 $\mathrm{KHB}+\mathrm{L}=40, \mathrm{~N}=5$ ) compared to $\mathrm{KHB}+\mathrm{L}$ of IRL 1 at $\mathrm{t} 2$ $(3,9 \pm 0,62$ peaks/min, $\mathrm{n}$ IRL $1 \mathrm{KHB}+\mathrm{L}=56, \mathrm{~N}=7)$.

\section{Effects of in vitro lidocaine supplementation on contractility of jejunal smooth muscle in vitro}

To assess the effect of lidocaine supplementation after resection of the intestinal segments $\mathrm{KBH}$ and $\mathrm{KBH}+\mathrm{L}$ muscle strips at each time point $t 1$ and +2 were compared for IRL 1 and IRL2 separately regarding their contractile performance. At $t 1$ the IRL 1 and IRL2 tissue showed no significant differences in frequency, amplitude and contractility, when different buffer conditions were used ( $\mathrm{KHB}$ or $\mathrm{KHB}+\mathrm{L})$. However, at $\mathrm{t} 2$ amplitude of contractions and contractility were significantly decreased in the IRL1 KHB tissues compared to IRL1 KHB+L muscle strips. The mean frequency of contractions did not show any differences between IRLI KHB and IRLI KHB $+\mathrm{L}$ at 12 . The IRL2 KHB tissues at $\mathrm{t} 2$ showed a significant decrease of frequency and amplitude of contractions compared to the IRL2 $\mathrm{KHB}+\mathrm{L}$ muscle strips. However, these changes in IRL2 KHB did not result in a significant change of contractility (Figure 1).

\section{Effect of time on contractility of jejunal smooth muscle in vitro}

To assess the effect of time in in vivo lidocaine treated tissues changes of IRLI and IRL2 from t1 to t2 were analyzed for each buffer condition $(\mathrm{KHB}, \mathrm{KHB}+\mathrm{L})$ separately. There is a significant decrease in frequency and an increase in amplitude of contractions as well as in contractility in IRL $1 \mathrm{KHB}+\mathrm{L}$ from t1 to t2. In IRL 1 KHB a similar significant decrease in frequency was observed but increase in amplitude of contractions and contractility was lacking from t1 to $t 2$. In IRL2 $\mathrm{KHB}+\mathrm{L}$ no changes of frequency, force and contractility over the time were observed. In contrast, IRL2 KHB expressed a decrease in frequency and a slight, but significant increase in amplitude. However, contractility of IRL2 KHB was not influenced by time. There was no significant difference of contractility between IRL1 +2 KHB-L and IRL2 +2 KHB-L, and IRL $1+1$ KHB-L and IRL $1+1$ KHB-L (Figure 1). 


\section{Discussion}

The present study presents a sequel study to the basic research approaches by Nieto et al. 2000 and Guschlbaver et al. $2010 a$ to improve the knowledge on lidocaine prokinetic effects in intestinal smooth muscle of horses. The present results are proving the hypothesis that a higher initial dose of lidocaine during IR in vivo could change and slightly improve but not impair the contractility of jejunal smooth muscle in vitro. The in vivo applied dosages of 1.3 and $2.6 \mathrm{mg} / \mathrm{kg}$ body weight over 10 minutes did result in only slight differences in contractile performance irrespectively of additive lidocaine supplemented to the smooth muscle samples during the initial period of the in vitro experiment. Only frequency of contractions was significantly enhanced over time in IRL2 samples supplemented with lidocaine additively. This indicates a small positive effect of the doubled lidocaine dosage on smooth
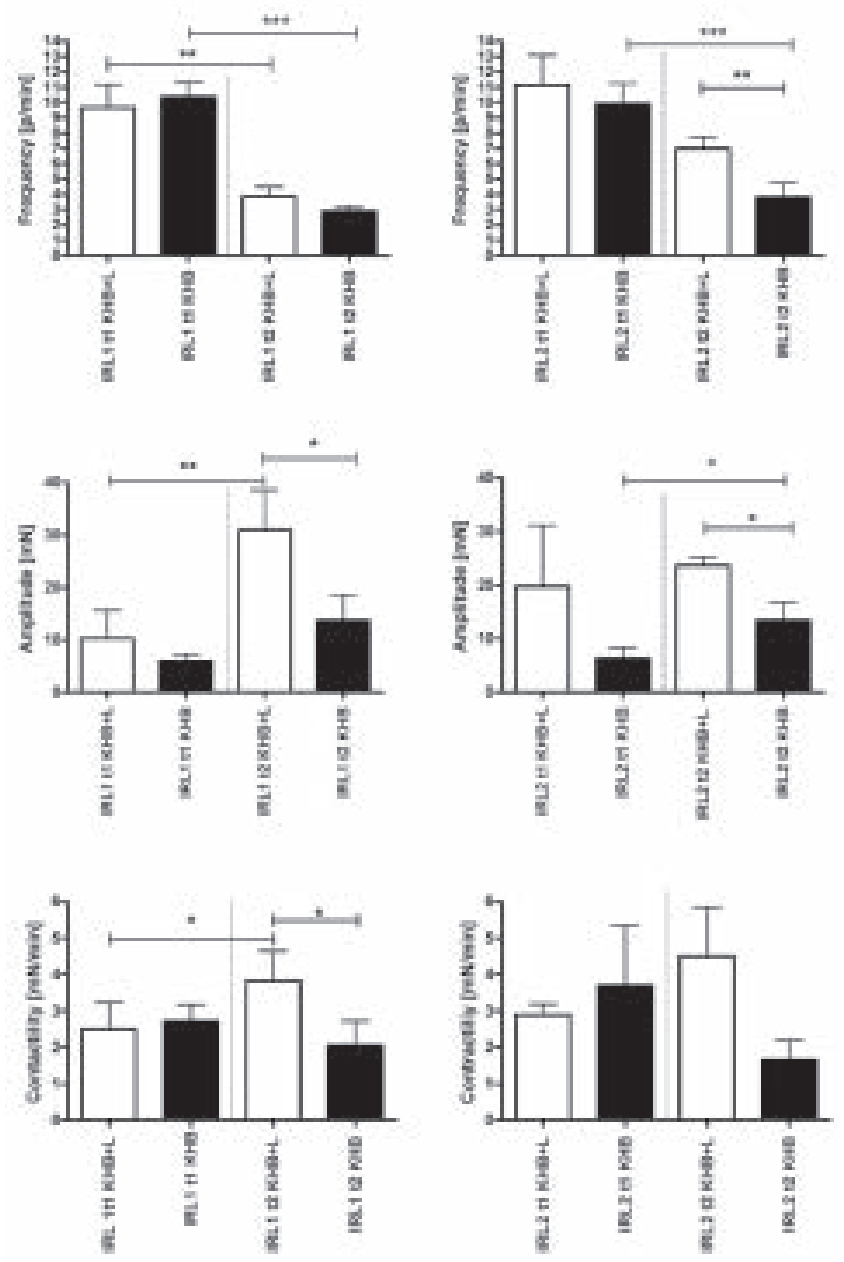

Fig. 1 Comparison of in vitro contractile activity (parameters frequency, amplitude, contractility) between IRL1 (left side) and IRL2 (right side) at different time points $(+1,+2)$ and different organ bath solutions $\{\mathrm{KHB}+\mathrm{L}(\square), \mathrm{KHB}(\boldsymbol{\square})\}$. Bars represents means \pm SEM $\left(\mathrm{n}_{\mathrm{IRLI} \text { KHB }}=28, \mathrm{n}_{\mathrm{IRLI}} \mathrm{KHB}+\mathrm{L}=56, \mathrm{n}_{\mathrm{IRL2} \text { KHB }}=20, \mathrm{n}_{\mathrm{IRL2} \text { KHB }+\mathrm{L}}=40\right)$. Significance levels are ${ }^{*} p<0.05,{ }^{* *} p<0.01,{ }^{* * *} p<0.001$.

Vergleich der kontraktilen Aktivität (Parameter: Frequenz, Amplitude, Kontraktilität) zwischen IRL 1 (links) und IRL2 (rechts) in vitro an unterschiedlichen Zeitpunkten $(t+,+2)$ und mit verschiedenen Pufferzusammensetzungen $\{K H B+L(\square), K H B(\square)\}$. Säulen geben Mittelwerte \pm $\operatorname{SEM}\left(n_{I R L I \text { KHB }}=28, n_{I R L I \mathrm{KHB}+L}=56, n_{I R L 2 \mathrm{KHB}}=20, n_{I R L 2 \mathrm{KHB}+L}=40\right)$ an. Signifikanzniveaus bei ${ }^{*} p<0.05,{ }^{* *} p<0.01,{ }^{* * *} p<0.001$. muscle and also interstitial cells of Cajal (ICC) function. Protection of ICC may have ameliorated the frequency of contractions (Engelking et al. 1987). We hypothesised that doubling the in vivo dosage led to lidocaine accumulation and provoked associated protective effects in tissues within the steady state phase observed in vitro. A steady state phase of lidocaine effect was observed in former in vitro experiments using IR-injured jejunal smooth muscle (Guschlbaver 2010a). Furthermore, a slight improvement was also observed regarding the in vitro contractile performance of IRL2 samples supplemented with lidocaine additively which was maintained steadier over time compared to the IRL $1 \mathrm{KHB}+\mathrm{L}$ samples. The previously described wash-out effect of lidocaine during in vitro incubation was reflected by the lower contractile activity for IRL1 KHB and IRL2 KHB muscle strips at $\mathrm{t} 2$ compared to $\dagger 1$. Hence sustainability of the effects of lidocaine can only be maintained by continuous application of lidocaine.

A limitation of this study is the time of IR-injury. Because this study is a sequel to Guschlbaver et al. (2010a, 2011), an IR of the intestinal wall of 15 min was chosen to impair smooth muscle contractility in vitro efficiently as it was determined by former studies. However, this short-term IR appear not to damage the intestinal wall macroscopically but histologically. Signs of cell damage such as edema were observed in a former study by Guschlbaver et al. (2010b). It should be clear that IR-time should be longer to extrapolate these results into a clinical background.

Addressing the question what relevance these experiments may have for clinical treatment of $\mathrm{POI}$, it has to be taken into account that the supplementation of $25 \mathrm{mg} / \mathrm{L}$ lidocaine in the $\mathrm{KHB}$ in vitro is much higher than measured effective serum concentrations (about $980 \mathrm{ng} / \mathrm{ml}$ ) in vivo by IV lidocaine infusion. However, the same dosage of lidocaine $\left(10^{-4} \mathrm{mmol} / \mathrm{L}\right)$ used in this experiment was also described as effective dose in vitro by Nieto et al. (2000). This discrepancy between in vivo and in vitro effective dosages might be based on certain biochemical features of lidocaine but cannot be explained satisfactorily yet. What we know so far is that pharmacokinetics of lidocaine in the horse are influenced by many factors such as general anesthesia or withholding of food (Fintl et al. 2010, Feary et al. 2005). Accumulation in the smooth muscle tissue could also account for the observed differences in effective dosages and has already been suggested (Guschlbaver et al. 2011).

\section{Summary and Conclusion}

An initial lidocaine bolus of $2.6 \mathrm{mg} / \mathrm{kg}$ applied IV during IRinjury slightly ameliorates smooth muscle contractile performance in vitro, but only when additive lidocaine is continuously supplemented to avoid a "wash out" over time. Pharmacokinetic studies are necessary to evaluate the body distribution of lidocaine and to assess the effective tissue lidocaine concentrations. The role of tissue lidocaine accumulation and its dynamic changes during lidocaine infusion should be elucidated to convey information about the cellular mechanisms of lidocaine's prokinetic effect. It should be clear that before recommending a higher lidocaine bolus in vivo for $\mathrm{POI}$ treatment further investigations are needed especially for: pharmacokinetic data for a higher $(2.6 \mathrm{mg} / \mathrm{kg} / 10 \mathrm{~min}$.) lido- 
cainebolus administered in vivo, the discrepancy between in vivo and in vitro lidocaine concentrations and intracellular and extracellular biochemics for lidocaine acting on the equine jejunal smooth muscle.

\section{Conflict of interest statement}

None of the authors has any financial or personal relationship that could inappropriately influence or bias the content of the paper.

\section{Animal welfare statement}

All animal procedures were approved by the State Office for Consumer Protection and Foof safety in accordance with the German Animal Welfare Law. Registration number: 33.1242502-04-07/1398.

\section{Acknowledgement}

The authors would like to thank Dr. Hopster for his excellent assistance during surgery of the horses.

\section{References}

Boddy G., Bong A., Cho W. and Daniel E. E. (2004) ICC pacing mechanisms in intact mouse intestine differ from those in cultured or dissected intestine. Am. J. Gastrointest. Liver Physiol. 286, G 653-662

Dickey E. J., McKenzie III H. C., Brown J. A. and Navas de Solis C. N. (2008) Serum concentrations of lidocaine and its metabolites after prolonged infusion in healthy horses. Equine Vet. J. 40, 348-352

Engelking L. R., Blyden G. T., Lofstedt J. and Greenblatt D. J. (1987) Pharmacokintetics of antipyrine, acetaminophen and lidocaine in fed and fasten horses. Vet. Pharmacol. Ther. 10, 73-83

Feary D. J., Mama K. R., Wagner A. E. and Thomasy S. (2005) Influence of general anesthesia on pharmacokinetics of intravenous lidocaine infusion in horses. Am. J. Vet. Res. 66, 574-580

Fintl C., Hudson N. P., Mayhew I. G., Edwards G. B., Proudman C. J. and Pearson G. T. (2004) Interstitial cells of Cajal (ICC) in equine colic: an immunohistochemical study of horses with obstructive disorders of the small and large intestines. Equine Vet. J. 36, 474-479..

Fintl C. and Hudson N. P. H. (2010) Interstitial cells of Cajal of the equine gastrointestinal tract: What we know so far. Equine Vet. J. $42,372-377$
Guschlbaver M., Hoppe S., Geburek F., Feige K. and Huber K. (2010a) In vitro effects of lidocaine on the contractility of equine jejunal smooth muscle challenged by ischemia-reperfusion injury. Equine Vet. J. 42, 53-58

Guschlbaver M., Slapa J., Huber K. und Feige K. (2010b) Lidocaine reduces tissue oedema formation in equine gut wall challenged by ischemia and reperfusion. Pferdeheilkunde 26, 531-534

Guschlbaver M., Feige K., Geburek F., Hoppe S., Hopster K., Pröpsting M. J. and Huber K. (2011) Effects of in vivo lidocaine administration at the time of ischemia and reperfusion on in vitro contractility of the equine jejunal smooth muscle. Am. J. Vet. Res. 72, 1449-1455

Herroreder S., Pecher S., Schönherr M. E., Kaulitz G., Hahnenkamp K., Friess H., Böttiger B. W., Baver H., Dijkgraaf M. G. W., Durieux M. E. and Hollmann M. W. (2007) Systemic lidocaine shortens length of hospital stay after colorectal surgery. Ann. Surg. 246, 192-200

Löscher W., Ungemach F. R. and Kroker R. (2003) Antiarrhythmika der Klasse IB: Lidokain und Phenytoin. In: Pharmakotherapie bei Haus- und Nutztieren. Berlin, Blackwell Verlag, 6th ed. p.130

Navas de Solis C., McKenzie III H. C. and McKenzie III L. V. (2007) Serum concentrations of lidocaine and its metabolites MEGX and GX during and after prolonged infusion of lidocaine after colic surgery. Journal of Equine Vet. Sci. 27, 398-404

Nieto J. E., Rakestraw P. C., Snyder J. R. and Vatistas N. J. (2000) In vitro effects of erythromycin, lidocaine, and metoclopramide on smooth muscle from the pyloric antrum, proximal portion of the duodenum, and middle portion of the jejunum of horses. Am. J. Vet. Res. 61, 413-419

Takaki M. (2003) Gut Pacemaker Cells: the Interstitial Cells of Cajal (ICC). Smooth Muscle Res. 39, 137-161

Takeo S., Tanonaka K., Shimizu K., Hirai K., Miyake K. and Minematsu R. (1989) Beneficial effects of lidocaine and disopyramide on oxygen-deficiency-induced contractile failure and metabolic disturbance in isolated rabbits hearts. Pharmacol. Experiment. Therap. 248, 306-314

Van Hoogmoed L. M., Nieto J. E., Spier S. J. and Snyder J. R. (2004) Survey of prokinetic use in horses with gastrointestinal injury. Vet. Surg. 33, 279-285

Dr. med. vet. Frauke Uhlendorf

Abteilung Innere Medizin

Klinik für Pferde

Stiftung Tierärztliche Hochschule Hannover

Bünteweg 9

30559 Hannover

frauke.uhlendorf@tiho-hannover.de 